Marquette University

e-Publications@Marquette

Biomedical Sciences Faculty Research and

Publications

Biomedical Sciences, Department of

$11-1-2013$

\title{
Oral Branched-Chain Amino Acid Supplements That Reduce Brain Serotonin During Exercise in Rats Also Lower Brain Catecholamines
}

\author{
Sujean Choi \\ Marquette University, sujean.choi@marquette.edu \\ Briana DiSilvio \\ University of Pittsburgh School of Medicine \\ Madelyn H. Fernstrom \\ University of Pittsburgh School of Medicine \\ John D. Fernstrom \\ University of Pittsburgh School of Medicine
}

Accepted version. Amino Acids, Vol. 45, No. 5 (November 2013): 1133-1142. DOI. (C) 2013 Springer. Used with permission.

Shareable Link. Provided by the Springer Nature SharedIt content-sharing initiative. 


\section{Oral Branched-Chain Amino Acid Supplements That Reduce Brain Serotonin during Exercise in Rats Also Lower Brain Catecholamines}

SuJean Choi

Department of Biomedical Sciences, Marquette University, Milwaukee, WI

Briana DiSilvio

Departments of Psychiatry, Pharmacology and Chemical Biology, University of Pittsburgh School of Medicine

Pittsburgh, PA

Madelyn H. Fernstrom

Departments of Psychiatry, Pharmacology and Chemical Biology, University of Pittsburgh School of Medicine Pittsburgh, PA

\section{John D. Fernstrom}

Departments of Psychiatry, Pharmacology and Chemical Biology, University of Pittsburgh School of Medicine UPMC/Western Psychiatric Institute and Clinic, Pittsburgh, $P A$

Abstract: Exercise raises brain serotonin release and is postulated to cause fatigue in athletes; ingestion of branched-chain amino acids (BCAA), by competitively inhibiting tryptophan transport into brain, lowers brain 
NOT THE PUBLISHED VERSION; this is the author's final, peer-reviewed manuscript. The published version may be accessed by following the link in the citation at the bottom of the page.

tryptophan uptake and serotonin synthesis and release in rats, and reputedly in humans prevents exercise-induced increases in serotonin and fatigue. This latter effect in humans is disputed. But BCAA also competitively inhibit tyrosine uptake into brain, and thus catecholamine synthesis and release. Since increasing brain catecholamines enhances physical performance, BCAA ingestion could lower catecholamines, reduce performance and thus negate any serotonin-linked benefit. We therefore examined in rats whether BCAA would reduce both brain tryptophan and tyrosine concentrations and serotonin and catecholamine synthesis. Sedentary and exercising rats received BCAA or vehicle orally; tryptophan and tyrosine concentrations and serotonin and catecholamine synthesis rates were measured $1 \mathrm{~h}$ later in hypothalamus. BCAA reduced hypothalamic tryptophan and tyrosine concentrations, and serotonin and catecholamine synthesis. These reductions in tyrosine concentrations and catecholamine synthesis, but not tryptophan or serotonin synthesis, could be prevented by co-administering tyrosine with BCAA. Complete essential amino acid mixtures, used to maintain or build muscle mass, were also studied, and produced different effects on hypothalamic tryptophan and tyrosine concentrations and serotonin and catecholamine synthesis. Since pharmacologically increasing brain catecholamine function improves physical performance, the finding that BCAA reduce catecholamine synthesis may explain why this treatment does not enhance physical performance in humans, despite reducing serotonin synthesis. If so, adding tyrosine to BCAA supplements might allow a positive action on performance to emerge.

Keywords: Exercise, Tryptophan, Tyrosine, Serotonin, Catecholamines, Rat

\section{Introduction}

One proposed use of branched-chain amino acids (BCAA) has been as an oral supplement to reduce mental fatigue and enhance physical performance in athletes (Newsholme and Blomstrand 1996). This application derives from the notion that the synthesis and release of the neurotransmitter serotonin (5-hydroxytryptamine, 5HT) by brain neurons is increased during exercise, leading to sleepiness and central fatigue (Newsholme and Blomstrand 1996). Serotonin is synthesized from tryptophan (TRP). Since the enzyme catalyzing the initial and rate-limiting step in $5 \mathrm{HT}$ synthesis (TRP hydroxylase) is only partly saturated at normal brain TRP concentrations, 5HT synthesis in brain neurons is readily influenced by local TRP concentrations (Fernstrom 1983). TRP concentrations, in turn, are directly modified by TRP uptake into brain. TRP uptake occurs via a competitive transport

Amino Acids, Vol. 45, No. 5 (November 2013): pg. 1133-1142. DOI. This article is C Springer and permission has been granted for this version to appear in e-Publications@Marquette. Springer does not grant permission for this article to be further copied/distributed or hosted elsewhere without the express permission from Springer. 
carrier, located at the blood-brain barrier (BBB), that it shares with several other large neutral amino acids (LNAA), including the BCAA (Pardridge 1979; Fernstrom 1983). Consequently, Newsholme proposed that the ingestion of BCAA in association with exercising could raise plasma BCAA concentrations sufficiently to block the uptake of TRP into brain and consequently reduce neuronal $5 \mathrm{HT}$ synthesis and release. The result would be to antagonize the rise in serotonin release that occurs during exercise and thus reduce fatigue (Newsholme and Blomstrand 1996). This hypothesis has been subjected to considerable experimentation. However, no consistent reduction in fatigue or improvement in physical performance has been found (Davis et al. 2000; Hobson et al. 2013).

But the administration of BCAA does not diminish just brain TRP uptake. It also reduces the uptake of tyrosine (TYR), since TYR is also an LNAA and shares the same competitive BBB transporter used by the BCAA (and TRP) (Pardridge 1979; Fernstrom 1983). TYR is the precursor of the catecholamine neurotransmitters [in brain, principally dopamine (DA) and norepinephrine (NE)]. Like TRP and 5HT, the rate of catecholamine synthesis and release by neurons in the central nervous system varies directly with TYR concentrations, under both physiologic and pharmacologic conditions (Wurtman et al. 1974; Carlsson and Lindqvist 1978; Fernstrom and Fernstrom 1987, 1995a). And, TYR uptake and catecholamine synthesis (and function) in brain are immediately reduced by the administration of LNAA, including the BCAA (Carlsson and Lindqvist 1978; Fernstrom and Fernstrom 1995b; McTavish et al. 1999; Gijsman et al. 2002). Since pharmacologic evidence supports the notion that increasing catecholamine action in brain can improve physical and mental performance (Watson et al. 2005; Meeusen et al. 2006), it seems possible that BCAA, postulated to reduce central fatigue by lowering $5 \mathrm{HT}$ function, may also reduce catecholamine synthesis and release, and thus cause central fatigue. Together, both effects of the BCAA (lowering both serotonin and catecholamines) might thus counterbalance each other in their actions on fatigue, and account for the equivocal effects that are seen on performance.

This study examined this idea from the biochemical perspective. In particular, we evaluated whether the administration of a mixture of

Amino Acids, Vol. 45, No. 5 (November 2013): pg. 1133-1142. DOI. This article is @ Springer and permission has been granted for this version to appear in e-Publications@Marquette. Springer does not grant permission for this article to be further copied/distributed or hosted elsewhere without the express permission from Springer. 
BCAA used previously to block exercise-induced increases in brain 5HT in rats (Smriga et al. 2002) would lower $5 \mathrm{HT}$ and catecholamines. As the outcome confirmed the hypothesis, we also examined if the inclusion of TYR with BCAA would block the BCAA effect on catecholamines. Finally, since essential amino acid mixtures, which contain BCAA, are used to increase muscle protein synthesis without consideration of possible effects on brain (Tipton et al. 1999), we examined how such essential amino acid supplements modify 5HT and catecholamines in brain. We focused on hypothalamus in this study, as this region shows clear effects of each precursor on the production rate of the respective transmitter (Fernstrom and Fernstrom 1995b, c). Hypothalamus is also one of the brain regions in which $5 \mathrm{HT}$ release has been shown to be increased by exercise and blocked by BCAA (Smriga et al. 2002). We studied 5HT and catecholamine synthesis rates, as synthesis reliably reflects neuronal release in amino acid experiments such as these (Gartside et al. 1992; McTavish et al. 1999; Rouch et al. 2003). Synthesis was quantitated using a simple, validated method that allows both $5 \mathrm{HT}$ and catecholamine synthesis to be measured in the same tissue samples. This method measures the in vivo activity of the initial, rate-limiting hydroxylation reactions [which convert TRP to 5-hydroxytryptophan (5HTP), and TYR to dihydroxyphenylalanine (DOPA)] following inhibition of the enzyme that decarboxylate 5HTP and DOPA to 5HT and DA, respectively (Carlsson and Lindqvist 1978). And, the effects of the amino acid mixtures studied on the competitive BBB uptake of TRP and TYR into the brain were evaluated by measuring plasma levels of the BCAA and aromatic amino acids [TRP, TYR, and phenylalanine (PHE)], and expressing these values as ratios of TRP and TYR to the sum of the other, competing LNAA. Such TRP and TYR ratios are reliable predictors of the effects on brain TRP and TYR concentrations of ingested amino acids and dietary proteins (Fernstrom and Wurtman 1972; Fernstrom et al. 1986; Fernstrom and Fernstrom 1995b). Finally, TRP and TYR concentrations were measured in cortex, as changes in this region are like those observed in other brain regions (including hypothalamus) under similar study conditions (e.g. Carlsson and Lindqvist 1978; Fernstrom and Fernstrom 1995b).

Amino Acids, Vol. 45, No. 5 (November 2013): pg. 1133-1142. DOI. This article is (c) Springer and permission has been granted for this version to appear in e-Publications@Marquette. Springer does not grant permission for this article to be further copied/distributed or hosted elsewhere without the express permission from Springer. 
NOT THE PUBLISHED VERSION; this is the author's final, peer-reviewed manuscript. The published version may be accessed by following the link in the citation at the bottom of the page.

\section{Materials and methods}

\section{General experimental procedures}

Male Sprague-Dawley rats (initial weight, 200-225 g; Hilltop Lab Animals, Scottdale, PA, USA) were housed individually, and acclimated to our animal quarters for at least 7 days before experimentation. During this time, water and food (Purina Rodent Laboratory Chow 5001, Purina Mills, St. Louis MO, USA) were provided ad libitum. The animals were exposed to $12 \mathrm{~h}$ of light daily (2000:0800 hours; i.e., reversed lighting cycle) and an ambient temperature of 22 ${ }^{\circ} \mathrm{C}$. All experiments were approved by the University of Pittsburgh Institutional Animal Care and Use Committee. At 1,900 h the day before an experiment, rats were deprived of food but not water. At $1,000 \mathrm{~h}$ the next morning ( $2 \mathrm{~h}$ into the daily dark period), groups of rats were given by intubation $10 \mathrm{ml} / \mathrm{kg}$ of water or one of the amino acid solutions described below. Thirty minutes later, all animals received an intraperitoneal injection of $m$-hydroxybenzylhydrazine (100 mg/kg; catalog number AC22903; Fisher Scientific, Pittsburgh PA, USA), an inhibitor of aromatic l-amino acid decarboxylase, to allow estimation of serotonin and catecholamine synthesis rates [via the linear accumulation of 5HTP and DOPA; see (Carlsson and Lindqvist 1978)] and were killed 30 min later by guillotine. The brains were rapidly removed and placed on an ice-cold glass plate. The hypothalamus and two pieces of fronto-parietal cerebral cortex (Paxinos and Watson 1982) were removed from each brain and rapidly frozen on dry ice. Blood was collected into glass tubes and allowed to clot in an ice bath. The sera were then harvested after centrifugation at $1,200 \times \mathrm{g}$ for $20 \mathrm{~min}$ at $4^{\circ} \mathrm{C}$ and aliquoted into microcentrifuge tubes. All samples were stored at $-80^{\circ} \mathrm{C}$ until assayed.

Some studies examined exercising rats that had been given free access ( $24 \mathrm{~h} /$ day) to running wheels for 7 days prior to experimentation. Rats were housed individually, and a running wheel was attached to each cage (Mini-Mitter, Bend OR, USA). Revolutions were detected via electronic switches on the wheels and recorded at 10 min intervals on a computer (Mini-Mitter, Bend OR, USA). Exercising rats were then used in experiments, with intubation

Amino Acids, Vol. 45, No. 5 (November 2013): pg. 1133-1142. DOI. This article is @ Springer and permission has been granted for this version to appear in e-Publications@Marquette. Springer does not grant permission for this article to be further copied/distributed or hosted elsewhere without the express permission from Springer. 
occurring $2 \mathrm{~h}$ into the daily dark period, followed 30 min later by $\mathrm{m}$ hydroxybenzylhydrazine (as described above and below). Distance was calculated using the wheel diameter $(0.33 \mathrm{~m})$ and the number of revolutions. The diurnal pattern of running activity from a typical study is shown in Fig. 1 for the 2-day period prior to the study. The arrow in the figure indicates the time of intubation, $2 \mathrm{~h}$ into the daily dark period, when the animals were actively running.

Fig. 1

Diurnal running activity in male rats. Rats were housed singly in cages containing running wheels for 7 days prior to experimentation. Hourly running activity is shown for the last 2 days and the first $2 \mathrm{~h}$ of the dark period preceding intubation of amino acid solutions. Data are mean \pm SEM $(n=16)$. Dark bars at bottom of figure indicate daily dark period (0800:2000 hours). Black arrow indicates start of experiment on the last day.

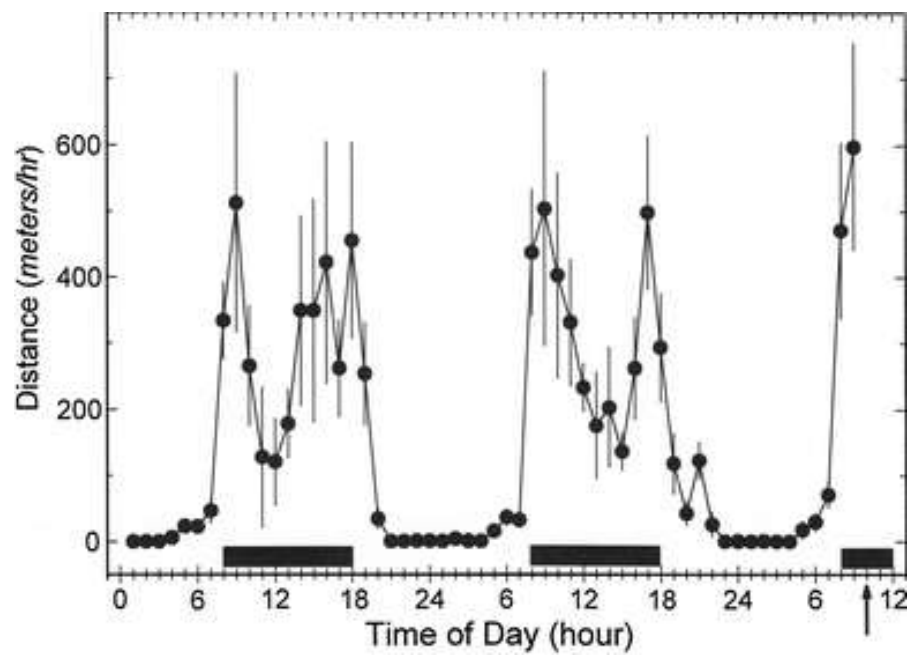

\section{Composition of amino acid mixtures}

We used the amino acid pattern employed by Smriga et al. (2002) to construct the amino acid solution administered as a BCAA mixture. They administered to rats per os a BCAA, glutamine, and arginine. The solution consisted of (mmol/l): leucine (LEU) 15.2, isoleucine (ILE) 9.9, valine (VAL) 11.1, glutamine 16.6, and arginine 13.9 (Smriga et al. 2002). The approximate weight of the rats was

Amino Acids, Vol. 45, No. 5 (November 2013): pg. 1133-1142. DOI. This article is C Springer and permission has been granted for this version to appear in e-Publications@Marquette. Springer does not grant permission for this article to be further copied/distributed or hosted elsewhere without the express permission from Springer. 
$275 \mathrm{~g}$ (range $260-280 \mathrm{~g}$ ), and they received $8 \mathrm{ml}$, giving a dose of each amino acid in the intubation mixture of $(\mathrm{mg} / \mathrm{kg})$ : LEU 58, ILE 38, VAL 38, glutamine 71 , and arginine 70 . We conducted a small preliminary study testing this amino acid mixture, administered to fasting rats by stomach tube at $10 \mathrm{ml} / \mathrm{kg}$. A dose containing twice the amount of each amino acid was also tested. Animals were examined 2 $\mathrm{h}$ after intubation. The higher dose produced significant effects in brain (reduction in TRP and TYR concentrations in cerebral cortex samples) and was thus employed in subsequent studies (those reported here). The composition of this solution is given in Table $\mathbf{1}$ as "BCAA". TYR was added to the BCAA mixture in some groups at a dose of 100 $\mathrm{mg} / \mathrm{kg}$. The amino acid pattern employed by Tipton et al. (1999) in an oral drink given to humans was used to construct the amino acid solution of one essential amino acid (EAA) mixture employed in our studies. This pattern approximates the essential amino acid composition of muscle protein (Tipton et al. 1999). We again performed a preliminary study using the dose listed in the table, and one-half of this dose, administered by stomach tube in $10 \mathrm{ml} / \mathrm{kg}$ water. The higher dose (listed in Table $\mathbf{1}$ as "EAA1") produced significant reductions in cortical tyrosine and was thus employed in subsequent experiments. A second EAA formulation was also tested, and was based in part on the EAA composition of a food (non-fat dry milk) (US Department of Agriculture, Agricultural Research Service 2006). This formulation employed LEU, ILE, VAL, arginine, and glutamine at the doses used by Smriga et al. (2002), and standardized the doses of the other EAA to the LEU content of non-fat dry milk. The EAA composition of non-fat dry milk is ( $\mathrm{g} / 100 \mathrm{~g}$ food): LEU 3.48, ILE 2.15, VAL 2.38, histidine 0.96, lysine 2.82, methionine 0.89, PHE 1.71, TYR 1.60, and TRP 0.50 (US Department of Agriculture, Agricultural Research Service 2006). Hence, for example, for histidine, the calculation was $0.96 / 3.48 \times 116=32 \mathrm{mg} / \mathrm{kg}$, and for lysine $2.82 / 3.48 \times 116=94 \mathrm{mg} / \mathrm{kg}$. This formulation is listed in Table 1 as "EAA2". Since the EAA2 formulation matched the amino acid composition of the BCAA formulation (for BCAA, arginine, glutamine), differences in the biochemical effects observed between the administrations of these two mixtures could be attributed to the additional amino acids present in the EAA2 formulation.

Amino Acids, Vol. 45, No. 5 (November 2013): pg. 1133-1142. DOI. This article is @ Springer and permission has been granted for this version to appear in e-Publications@Marquette. Springer does not grant permission for this article to be further copied/distributed or hosted elsewhere without the express permission from Springer. 
NOT THE PUBLISHED VERSION; this is the author's final, peer-reviewed manuscript. The published version may be accessed by following the link in the citation at the bottom of the page.

Table 1

Composition of oral amino acid mixtures

\begin{tabular}{|l|l|l|l|}
\hline & BCA & EAA1 & EA \\
\hline Amino & acid & (mg/kg body weight) & \\
\hline Leucine & 116 & 166 & 116 \\
\hline Isoleucine & 76 & 80 & 76 \\
\hline Valine & 76 & 86 & 76 \\
\hline Glutamine & 142 & - & 142 \\
\hline Arginine & 140 & - & 140 \\
\hline Histidine & - & 56 & 32 \\
\hline Lysine & - & 142 & 94 \\
\hline Methionine & - & 44 & 30 \\
\hline Phenylalanine & - & 42 & 57 \\
\hline Threonine & - & 52 & 53 \\
\hline Tryptophan & - & 22 & 17 \\
\hline
\end{tabular}

The BCAA mixture is derived from a mixture employed by Smriga et al. (2002). Tyrosine was added to the BCAA mixture in some experimental groups at a dose of $100 \mathrm{mg} / \mathrm{kg}$. The EAA1 mixture is derived from that of Tipton et al. (1999). The EAA2 mixture is derived from the EAA pattern of non-fat dried milk (US Department of Agriculture, Agricultural Research Service 2006), as described in "Materials and methods". Solutions were prepared in deionized water just prior to intubation at concentrations that provided the above dosages when administered orally to rats at 10 $\mathrm{ml} / \mathrm{kg}$

\section{Specific experiment}

Experiment 1 (Fig. 2) was a small, preliminary study to determine the optimal time to measure the responses to BCAA intubation. Groups of three rats, fasted during the daily dark period received the BCAA solution ( $10 \mathrm{ml} / \mathrm{kg}$; see Table $\mathbf{1}$ ) and were killed $30,60,90$, or 120 min later. Thirty minutes before sacrifice, they received an injection of $m$-hydroxybenzylhydrazine. Control rats were intubated with water, followed immediately by an injection of $m$ hydroxybenzylhydrazine, and killed 30 min later. Experiment 2.1 (Table 2, Sedentary rats) examined in non-exercising rats the effect of the BCAA solution with or without TYR, administered $1 \mathrm{~h}$ before sacrifice (the optimal time identified in experiment 1 ). Groups of seven

Amino Acids, Vol. 45, No. 5 (November 2013): pg. 1133-1142. DOI. This article is @ Springer and permission has been granted for this version to appear in e-Publications@Marquette. Springer does not grant permission for this article to be further copied/distributed or hosted elsewhere without the express permission from Springer. 
sedentary rats received the BCAA or the BCAA + TYR solution (10 $\mathrm{ml} / \mathrm{kg}$; see Table 1) $2 \mathrm{~h}$ into the daily dark period and were killed 60 min later. Thirty minutes before sacrifice, they received $m$ hydroxybenzylhydrazine. Experiment 2.2 (Table 2, Exercising rats) was identical in design to experiment 2.1 above, except that exercising rats were studied, and the group size was 5-6 (only 16 running wheel cages were available). Experiment 3.1 (Table 3, Sedentary rats) compared in sedentary rats ( $n=7 /$ group) the effect of intubating the BCAA solution with that of a complete EAA mixture similar to that used by exercising humans (EAA1 in Table 1) (Tipton et al. 1999). The timing of the experiment was identical to that in experiment 2.1. Experiment 3.2 (Table 3, Exercising rats) was identical in design to experiment 3.1, except that exercising rats were studied ( $n=5-$ $6 /$ group). Experiment 4 (Table 4 ) compared in sedentary rats only ( $n$ $=7 /$ group) the effect of intubating the BCAA solution with that of a second, complete essential amino acid mixture (EAA2 in Table $\mathbf{1}$ ). EAA2 mirrored the BCAA composition of the BCAA solution, but contained the other EAAs in proportion to their pattern in non-fat dried milk (see above). The timing of the experiment was identical to that in experiments 2.1 and 3.1 .

\section{Fig. 2}

Time course of the effects of an oral amino acid mixture containing BCAA on aromatic amino acids in brain. Rats ( $n=3$ /group) fasted during the daily light period were intubated $2 \mathrm{~h}$ into the daily dark period with a solution containing branched-chain amino acids ("BCAA" formulation in Table $\mathbf{1}$ ). Thirty minutes before sacrifice, they received an injection of $m$-hydroxybenzylhydrazine (100 mg/kg ip). Control rats were intubated with water, followed immediately by $m$ hydroxybenzylhydrazine injection, and killed 30 min later. Data are presented as mean \pm SEM. Serum TRP and TYR concentrations did not differ significantly from control values at any time, although a significant main effect was present (ANOVA, $P<0.05$ ). For the serum TRP and TYR ratios, and brain TRP and TYR concentrations, the value at each time point differed significantly from control values (ANOVA, Newman-Keuls test, $P<0.01)$. DOPA values did not differ from control at any time (the main effect was not significant; ANOVA, $P>$ $0.05)$; and 5HTP values differed significantly from control values, but

Amino Acids, Vol. 45, No. 5 (November 2013): pg. 1133-1142. DOI. This article is @ Springer and permission has been granted for this version to appear in e-Publications@Marquette. Springer does not grant permission for this article to be further copied/distributed or hosted elsewhere without the express permission from Springer. 
NOT THE PUBLISHED VERSION; this is the author's final, peer-reviewed manuscript. The published version may be accessed by following the link in the citation at the bottom of the page.

only at $60 \min (P<0.01$, Newman-Keuls test; the main effect was significant, ANOVA, $P<0.01$ )

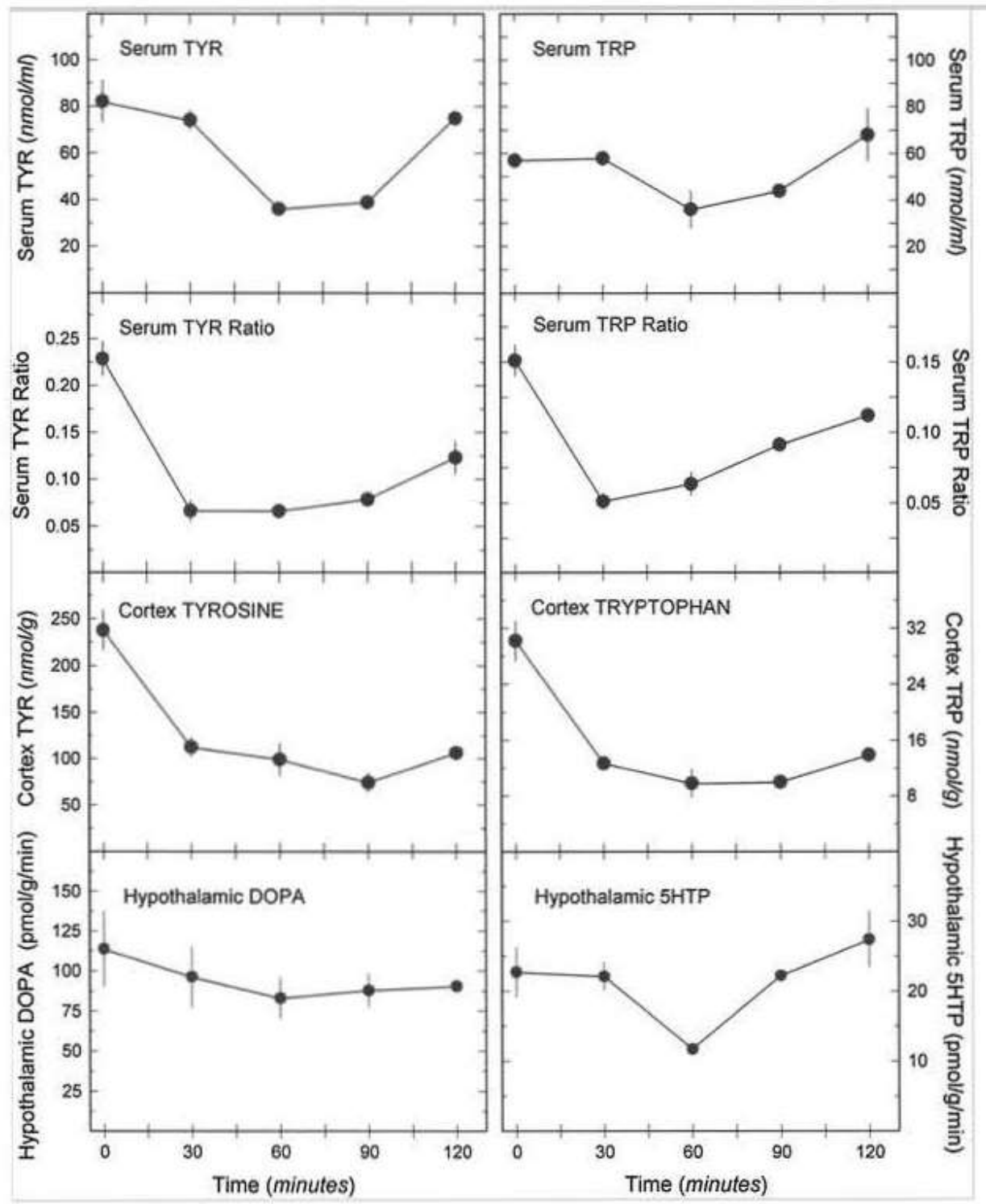

Amino Acids, Vol. 45, No. 5 (November 2013): pg. 1133-1142. DOI. This article is @ Springer and permission has been granted for this version to appear in e-Publications@Marquette. Springer does not grant permission for this article to be further copied/distributed or hosted elsewhere without the express permission from Springer. 
NOT THE PUBLISHED VERSION; this is the author's final, peer-reviewed manuscript. The published version may be accessed by following the link in the citation at the bottom of the page.

Table 2

Effects in sedentary and exereising rats of the oral ingestion of BCAA with or without TYR on TYR and TRP concentrations and DOPA and SHTP synthesis rates in the central nervous system

\begin{tabular}{|c|c|c|c|}
\hline Variable & Vehicle & BCAA & BCAA + TYR \\
\hline \multicolumn{4}{|l|}{ Sedentary rats } \\
\hline Serum TYR $(\mathrm{nmol} / \mathrm{ml})$ & $65.6 \pm 4.3$ & $29.0 \pm 1.9^{1}$ & $155.7 \pm 9.2^{1,2}$ \\
\hline Serum TYR ratio & $0.214 \pm 0.006$ & $0.046 \pm 0.003^{1}$ & $0.280 \pm 0.011^{1.2}$ \\
\hline Cortex TYR $(\mathrm{nmol} / \mathrm{g})$ & $108.0=7.0$ & $36.6 \pm 4.0^{1}$ & $127.3 \pm 9.9^{2}$ \\
\hline Hypothalamic DOPA (pmol/g/min) & $63 \pm 5$ & $47 \pm 4^{1}$ & $67 \pm 4^{2}$ \\
\hline Serum TRP (nmol/ml) & $35.3 \pm 3.4$ & $24.0 \pm 6.6^{1}$ & $22.6 \pm 2.4^{1}$ \\
\hline Serum TRP ratio & $0.105 \pm 0.008$ & $0.038 \pm 0.003^{1}$ & $0.033 \pm 0.003^{1}$ \\
\hline Cortex TRP $(\mathrm{nmol} / \mathrm{g})$ & $22.4 \pm 1.7$ & $4.7 \pm 0.7^{1}$ & $6.2 \pm 0.9^{1}$ \\
\hline Hypothalamic $5 \mathrm{HTP}(\mathrm{pmol} / \mathrm{g} / \mathrm{min})$ & $23 \pm 2$ & $12 \pm 1^{1}$ & $12 \pm 1^{1}$ \\
\hline \multicolumn{4}{|l|}{ Exercising rats } \\
\hline Serum TYR (nmol/ml) & $80.7 \pm 10.0$ & $66.8 \pm 9.2$ & $155.2 \pm 23.6^{1,2}$ \\
\hline Serum TYR ratio & $0.193 \pm 0.010$ & $0.118 \pm 0.015^{1}$ & $0.243 \pm 0.017^{1,2}$ \\
\hline Cortex TYR $(\mathrm{nmol} / \mathrm{g})$ & $87.7 \pm 10.6$ & $63.5 \pm 12.1$ & $111.6=10.8^{2}$ \\
\hline Hypothalamic DOPA (pmol/g/min) & $72 \pm 2$ & $62 \pm 1^{1}$ & $78 \pm 3^{2}$ \\
\hline Serum TRP $(\mathrm{nmol} / \mathrm{ml})$ & $68.4 \pm 3.6$ & $63.3 \pm 6.5$ & $69.9 \pm 12.7$ \\
\hline Serum TRP ratio & $0.164=0.011$ & $0.111+0.011^{1}$ & $0.097 \pm 0.011^{1}$ \\
\hline Cortex TRP $(\mathrm{nmol} / \mathrm{g})$ & $27.6 \pm 3.5$ & $15.1 \pm 3.0^{1}$ & $10.9 \pm 2.2^{1}$ \\
\hline Hypothalamic 5HTP (pmol/g/min) & $26 \pm 1$ & $17 \pm 1^{1}$ & $17 \pm 1^{1}$ \\
\hline
\end{tabular}

Sedentary experiment Groups of seven sedentary male rats were fasted during the daily light period; $2 \mathrm{~h}$ into the dark period, they were intubated with either water (vehicle), a solution containing branchedchain amino acids ("BCAA", formulation given in column one of Table 1), or the same solution containing in addition $100 \mathrm{mg} / \mathrm{kg}$ TYR ("BCAA + TYR"; see "Materials and methods")

Exercising experiment Groups of 5-6 male rats were housed in plastic tubs containing running wheels for 7 days prior to experimentation. On day 7 , rats were deprived of food during the light period, and $2 \mathrm{~h}$ into the dark period, intubated with the same solutions administered to the sedentary rats. In both experiments, $30 \mathrm{~min}$ after intubation, all rats

Amino Acids, Vol. 45, No. 5 (November 2013): pg. 1133-1142. DOI. This article is C Springer and permission has been granted for this version to appear in e-Publications@Marquette. Springer does not grant permission for this article to be further copied/distributed or hosted elsewhere without the express permission from Springer. 
NOT THE PUBLISHED VERSION; this is the author's final, peer-reviewed manuscript. The published version may be accessed by following the link in the citation at the bottom of the page.

received an injection of $m$-hydroxybenzylhydrazine (100 mg/kg ip), and were killed 30 min thereafter. Data are mean \pm SEM $^{1} P \leq 0.05$ vs. vehicle; ${ }^{2} P \leq 0.05$ vs. BCAA (ANOVA; Neuman-Keuls test)

Table 3

Effects in sedentary and exereising rats of the oral ingestion of branched-chain amine acids or essential amino acids (E.AA1: muscle protein pattern) on TYR and TRP concentrations and DOPA and 5HTP synthesis rates in the central nervous system

\begin{tabular}{|c|c|c|c|}
\hline Variable & Vehicle & BCAA & EAAI \\
\hline \multicolumn{4}{|l|}{ Sedentary rats } \\
\hline Serum TYR $(\mathrm{nmol} / \mathrm{ml})$ & $76.8 \pm 2.9$ & $34.8 \pm 1.8^{1}$ & $55,8 \pm 3.8^{1,2}$ \\
\hline Serum TYR ratio & $0.215 \pm 0.005$ & $0.058 \pm 0.002^{1}$ & $0.105 \pm 0.008^{1,2}$ \\
\hline Cortex TYR (nmol/g) & $89.3 \pm 6.2$ & $34.5 \pm 3.6^{1}$ & $54.3 \pm 4.9^{1.2}$ \\
\hline Hypothalamus DOPA (pmol/g/min) & $71.9 \pm 2.3$ & $50.0 \pm 1.2^{1}$ & $59.1 \pm 2.4^{1,2}$ \\
\hline Serum TRP $(\mathrm{nmol} / \mathrm{ml})$ & $43.9 \pm 3.5$ & $29.7 \pm 2.3^{1}$ & $58.8 \pm 2.7^{1,2}$ \\
\hline Serum TRP ratio & $0.113 \pm 0.009$ & $0.048 \pm 0.002^{1}$ & $0.122 \pm 0.008^{2}$ \\
\hline Cortex TRP $(\mathrm{nmol} / \mathrm{g})$ & $22.4 \pm 1.3$ & $11.4 \pm 1.4^{1}$ & $21.9 \pm 2.2^{2}$ \\
\hline Hypothalamus 5HTP (pmol/g/min) & $32.1 \pm 1.6$ & $11.8 \pm 0.8^{1}$ & $28.7 \pm 1.5^{2}$ \\
\hline \multicolumn{4}{|l|}{ Exercising rats } \\
\hline Serum TYR $(\mathrm{nmol} / \mathrm{ml})$ & $74.9 \pm 5.0$ & $35.2 \pm 2.6^{1}$ & $57.9 \pm 3.4^{1.2}$ \\
\hline Serum TYR ratio & $0.212=0.005$ & $0.078=0.008^{1}$ & $0.111 \pm 0.005^{1.2}$ \\
\hline Cortex TYR $(\mathrm{nmol} / \mathrm{g})$ & $59.5 \pm 4.5$ & $26.3 \pm 3.5^{1}$ & $37.3 \pm 0.6^{1,2}$ \\
\hline Hypothalamus DOPA (pmol $\mathrm{g} / \mathrm{min}$ ) & $74.6 \pm 3.5$ & $56.2 \pm 5.7^{1}$ & $58.5 \pm 3.7^{1}$ \\
\hline Serum TRP $(\mathrm{nmol} / \mathrm{ml})$ & $73.8 \pm 1.7$ & $44.4=1.5^{1}$ & $93.1 \pm 3.4^{1,2}$ \\
\hline Serum TRP ratio & $0.194=0.006$ & $0.099 \pm 0.005^{1}$ & $0.184 \pm 0.015^{2}$ \\
\hline Cortex TRP (nmol/g) & $16.3 \pm 1.8$ & $6.7 \pm 1.0^{1}$ & $15.7 \pm 1.6^{2}$ \\
\hline Hypothalamus 5HTP (pmol/g/min) & $28.4 \pm 2.1$ & $15.4 \pm 1.4^{1}$ & $27.9 \pm 1.8^{2}$ \\
\hline
\end{tabular}

Sedentary experiment Groups of seven sedentary male rats were fasted during the daily light period, and then $2 \mathrm{~h}$ into the dark period, intubated with either water (vehicle), a solution containing branched-chain amino acids ("BCAA" formulation in Table 1 ), or a solution containing essential amino acids ("EAA1" formulation in Table 1 )

Exercising experiment Groups of 5-6 male rats were housed in plastic tubs containing running wheels for 7 days prior to experimentation. On day 7 , rats were deprived of food during the light period, and $2 \mathrm{~h}$ into the dark period, intubated with the same

Amino Acids, Vol. 45, No. 5 (November 2013): pg. 1133-1142. DOI. This article is @ Springer and permission has been granted for this version to appear in e-Publications@Marquette. Springer does not grant permission for this article to be further copied/distributed or hosted elsewhere without the express permission from Springer. 
NOT THE PUBLISHED VERSION; this is the author's final, peer-reviewed manuscript. The published version may be accessed by following the link in the citation at the bottom of the page.

solutions administered to the sedentary rats. In both experiments, 30 min after intubation, all rats received an injection of $m$-hydroxybenzylhydrazine $(100 \mathrm{mg} / \mathrm{kg}$ ip), and were killed 30 min thereafter. Data are mean \pm SEM

${ }^{1} P \leq 0.05$ vs. vehicle; ${ }^{2} P \leq 0.05$ vs. BCAA (ANOVA; Neuman-Keuls test)

\section{Table 4}

Effects in sedentary rats of the oral ingestion of BCAA or essential amino acids (EAA2: partial non-fat dry milk: protein pattern) on TYR and TRP concentrations and DOPA and SHTP synthesis rates in the central nervous system

\begin{tabular}{|l|l|l|l|}
\hline Variable & Vehicle & BCAA & EAA2 \\
\hline Serum TYR $(\mathrm{nmol} / \mathrm{ml})$ & $82.4 \pm 4.6$ & $39.8 \pm 1.4^{1}$ & $97.7 \pm 4.9^{1,2}$ \\
\hline Serum TYR ratio & $0.219 \pm 0.008$ & $0.062 \pm 0.005^{1}$ & $0.164 \pm 0.006^{1.2}$ \\
\hline Cortex TYR $(\mathrm{nmol} / \mathrm{g})$ & $81.2 \pm 7.4$ & $41.8 \pm 3.4^{1}$ & $87.8 \pm 6.0^{2}$ \\
\hline Hypothalamus DOPA $(\mathrm{pmol} / \mathrm{g} / \mathrm{min})$ & $66 \pm 4$ & $49 \pm 4^{1}$ & $72 \pm 3^{2}$ \\
\hline Serum TRP $(\mathrm{nmol} / \mathrm{ml})$ & $50.7 \pm 4.0$ & $38.1 \pm 2.8^{1}$ & $82.6 \pm 4.6^{1,2}$ \\
\hline Serum TRP ratio & $0.123 \pm 0.006$ & $0.060 \pm 0.006^{1}$ & $0.135 \pm 0.004^{2}$ \\
\hline Cortex TRP $(\mathrm{nmol} / \mathrm{g})$ & $19.6 \pm 1.8$ & $8.1 \pm 0.5^{1}$ & $21.0 \pm 2.3^{2}$ \\
\hline Hypothalamus $5 \mathrm{HTP}(\mathrm{pmol} / \mathrm{g} / \mathrm{min})$ & $34 \pm 3$ & $15 \pm 2^{1}$ & $30 \pm 3^{2}$ \\
\hline
\end{tabular}

Groups of seven sedentary male rats were fasted during the daily light period, and then $2 \mathrm{~h}$ into the following dark period, intubated with either water (vehicle), a solution containing branched-chain amino acids ("BCAA" formulation in Table $\mathbf{1}$ ), or a solution containing essential amino acids ("EAA2" formulation in Table $\mathbf{1}$ ). Thirty minutes later, they received an injection of $m$-hydroxybenzylhydrazine $(100 \mathrm{mg} / \mathrm{kg}$ ip) and were killed $30 \mathrm{~min}$ thereafter. Data are mean $\pm \mathrm{SEM}$ ${ }^{1} P \leq 0.05$ vs. vehicle; ${ }^{2} P \leq 0.05$ vs. BCAA (ANOVA, Neuman-Keuls test)

\section{Chemical measurements}

LNAA were assayed in serum and cerebral cortex using reversed phase HPLC and electrochemical detection, as previously described (Bongiovanni et al. 2001; Choi et al. 2009). Concentrations of individual amino acids were calculated using the external standard method, and brain values were corrected for recovery. The serum ratio for a given amino acid is the concentration of that amino (in $\mathrm{nmol} / \mathrm{ml}$ ) acid divided by the sum of the concentrations of its transport competitors $[$ serum TYR ratio $=$ TYR $/($ TRP + PHE + LEU + ILE + VAL); serum TRP ratio $=\mathrm{TRP} /($ TYR $+\mathrm{PHE}+\mathrm{LEU}+\mathrm{ILE}+\mathrm{VAL})]$, and is an

Amino Acids, Vol. 45, No. 5 (November 2013): pg. 1133-1142. DOI. This article is C Springer and permission has been granted for this version to appear in e-Publications@Marquette. Springer does not grant permission for this article to be further copied/distributed or hosted elsewhere without the express permission from Springer. 
accurate index of the effect of treatments that modify plasma LNAA pattern on the competitive uptake of TRP and TYR into brain (Fernstrom and Wurtman 1972; Fernstrom and Faller 1978; Fernstrom 1983). 5HTP and DOPA were measured in hypothalamic samples by HPLC/electrochemical detection (using a-methyldopa as an internal standard), as previously described (Choi et al. 2009). Calculations were made using the internal standard method.

\section{Statistics}

Data are reported as mean \pm SEM. They were analyzed statistically using either the Student's $t$ test or one-way analysis of variance and post hoc testing using the Newman-Keuls test (SigmaPlot 11, Systat Software, San Jose CA, USA).

\section{Results}

In a small study, we first assessed the time course of the changes in the variables of interest: serum TRP and TYR concentrations and the TRP and TYR ratios (which predict TRP and TYR uptake into brain; Fernstrom and Wurtman 1972), the concentrations of TRP and TYR in brain, and the rates at which these amino acids are converted to their neurotransmitter products, 5HT and catecholamines, respectively. Following oral intubation with the "BCAA" mixture to sedentary rats (see Table $1 ; n=3$ /group), serum TRP and TYR concentrations showed nonsignificant reductions; the serum TRP and TYR ratios, and cortical TRP and TYR concentrations dropped markedly at 30 min (Fig. 2). Cortical TRP and TYR concentrations remained low for the duration of the study (120 $\mathrm{min})$, while the ratios began to recover at 90-120 min. DOPA and 5HTP synthesis dropped to nadir values at 60 min; DOPA synthesis remained low, while 5HTP synthesis had rebounded by 120 min (bottom panels, Fig. 2). Inasmuch as the maximal effects on DOPA and 5HTP synthesis occurred $60 \mathrm{~min}$ following intubation, all subsequent studies used $60 \mathrm{~min}$ as the experimental endpoint.

We next examined the impact of administering the BCAA mixture 60 min before sacrifice to sedentary rats (with $m$ hydroxybenzylhydrazine injected 30 min after amino acid intubation in

Amino Acids, Vol. 45, No. 5 (November 2013): pg. 1133-1142. DOI. This article is @ Springer and permission has been granted for this version to appear in e-Publications@Marquette. Springer does not grant permission for this article to be further copied/distributed or hosted elsewhere without the express permission from Springer. 
this and all subsequent experiments), to evaluate the effects in larger groups of animals ( $n=7 /$ group). The results are presented in Table $\mathbf{2}$ (Sedentary rats). As in the first study, intubation of the BCAA mixture significantly reduced the serum TYR ratio (and serum TYR itself), cortex TYR concentrations, and DOPA synthesis rate in hypothalamus. This treatment also reduced serum TRP concentrations, the serum TRP ratio and cortical TRP concentrations, and hypothalamic 5HTP synthesis, compared to vehicle values. In this study, we also evaluated the impact of adding TYR to the BCAA mixture to ascertain if its addition would ameliorate the effect on cortical TYR concentrations and DOPA synthesis. The inclusion of TYR in the intubation solution (at a dose of $100 \mathrm{mg} / \mathrm{kg}$ ) can be seen in Table $\mathbf{2}$ (Sedentary rats) to prevent completely the drop in cortical TYR concentrations produced by the BCAA mixture alone and to block the decline in hypothalamic DOPA synthesis. Not surprisingly, since TYR, like the BCAA, competes with TRP for brain uptake (Pardridge and Oldendorf 1975), cortical TRP concentrations and hypothalamic 5HTP synthesis remained depressed in animals receiving TYR in the BCAA mixture (Table $\mathbf{2}$, Sedentary rats).

The experiment with BCAA and TYR was also conducted in exercising rats, since the BCAA treatment was originally developed for use in humans during exercise (Blomstrand et al. 1991). Rats were given free access to a home cage running wheel for 7 days prior to experimentation. In this experiment, the rats ran $3.94 \pm 0.79 \mathrm{~km}$ during the 24-h period prior to the experiment (Fig. 1 presents data from this study). The experiment began $2 \mathrm{~h}$ into the daily dark period. During the initial $2 \mathrm{~h}$ period of darkness, the rats ran $1.07 \pm 0.28 \mathrm{~km}$. At $2 \mathrm{~h}$, rats ( $n=5-6 /$ group) received vehicle, the BCAA mixture or the BCAA mixture containing TYR (at $100 \mathrm{mg} / \mathrm{kg}$ ), as in the study above. $m$-Hydroxybenzylhydrazine was injected 30 min thereafter, and the rats were killed 30 min later. Because the schedule was involved (injections and intubations were timed so that rats could be sacrificed every $3 \mathrm{~min}$ ), the animals were not allowed to run during the treatment period. In these rats, intubation of the BCAA mixture reduced the serum TYR ratio, cortical TYR concentrations (though not significantly in this particular experiment) and hypothalamic DOPA synthesis, compared to vehicle values (Table 2, Exercising rats). BCAA treatment significantly reduced the serum TRP ratio, cortex TRP

Amino Acids, Vol. 45, No. 5 (November 2013): pg. 1133-1142. DOI. This article is @ Springer and permission has been granted for this version to appear in e-Publications@Marquette. Springer does not grant permission for this article to be further copied/distributed or hosted elsewhere without the express permission from Springer. 
concentrations, and hypothalamic 5HTP synthesis (Table 2, Exercising rats). The coadministration of TYR with the BCAA mixture elevated the serum TYR ratio above those observed in vehicle and BCAA-treated rats, and prevented the decline in cortical TYR concentrations and hypothalamic DOPA synthesis observed in rats treated with BCAA alone. The administration of TYR with BCAA was associated with significant reductions in the serum TRP ratio, cortical TRP concentrations, and hypothalamic 5HTP synthesis.

Essential amino acid formulations are also employed by athletes to optimize muscle performance. While they contain BCAA, and might thus be expected to reduce TRP, TYR and their transmitter products in brain, they also contain TRP and PHE (the TYR precursor), which might be hypothesized to offset effects of the BCAA. To examine this possibility, we evaluated an EAA formulation adapted from the work of Tipton et al. (1999) in humans (approximates the EAA pattern of muscle protein; see "Materials and methods" and EAA1 in Table 1). Initial studies employed sedentary rats and compared the EAA1 formulation to vehicle and the BCAA formulation (included as a "positive control" group). Groups of seven rats received an oral dosing of vehicle, BCAA, or EAA1; an injection of $m$-hydroxybenzylhydrazine followed after $30 \mathrm{~min}$, and animals were killed $30 \mathrm{~min}$ later. The experiment began $2 \mathrm{~h}$ into the daily dark period. As observed in earlier studies, the BCAA mixture lowered serum TYR concentrations and the serum TYR ratio, cortical TYR levels and hypothalamic DOPA synthesis, compared to vehicle (control) values (Table 3, Sedentary rats). Serum TRP concentrations, the serum TRP ratio, cortical TRP levels, and hypothalamic 5HTP synthesis rate were also significantly depressed. While the administration of the EAA1 mixture also significantly reduced all TYR and DOPA values (Table 3, Sedentary rats), the decline (relative to control values) was less than that observed following BCAA ingestion (note in Table 3 that TYR and DOPA values in the EAA1 animals differed significantly from corresponding values in BCAA rats). In addition, the ingestion of the EAA1 mixture was in all cases not associated with reductions in TRP variables or 5HTP synthesis, compared to vehicle values (Table 3, Sedentary rats).

This study was also conducted in exercising rats given free access to home cage running wheels for 7 days before

Amino Acids, Vol. 45, No. 5 (November 2013): pg. 1133-1142. DOI. This article is (c) Springer and permission has been granted for this version to appear in e-Publications@Marquette. Springer does not grant permission for this article to be further copied/distributed or hosted elsewhere without the express permission from Springer. 
experimentation. In this experiment, the rats ran $3.30 \pm 0.35 \mathrm{~km}$ during the 24- $\mathrm{h}$ period prior to the experiment. The experiment began $2 \mathrm{~h}$ into the dark period, and during the 2-h period of darkness, the rats ran $1.02 \pm 0.10 \mathrm{~km}$. At $2 \mathrm{~h}$, groups of seven rats received vehicle, the BCAA or the EAA1 mixture, $m$-hydroxybenzylhydrazine $30 \mathrm{~min}$ thereafter, and were killed 30 min later. The animals were not allowed to run during the treatment period. Intubation of the BCAA mixture significantly reduced serum TYR and the TYR ratio, cortical TYR concentrations and hypothalamic DOPA synthesis, compared to vehicle values (Table 3, Exercising rats). Serum TRP and the TRP ratio, cortex TRP concentrations, and hypothalamic 5HTP synthesis were also significantly reduced. The administration of the EAA1 mixture also significantly reduced serum TYR, the TYR ratio, cortical TYR concentrations and hypothalamic DOPA synthesis, but the effects were less than those observed after BCAA administration (Table 3, Exercising Rats). And, as in sedentary rats, EAA1 intubation did not lower any of the TRP or 5HTP measures, relative to vehicle control values.

Finally, we evaluated in sedentary rats a second EAA formulation, adapted from the EAA pattern of milk, but with the BCAA contents of the "BCAA" mixture (EAA2 in Table 1; see "Materials and methods"). In this experiment, EAA2 was compared to vehicle and BCAA ("positive control") treatments ( $n=7 /$ group). As before, BCAA administration significantly lowered all TYR, DOPA, TRP, and 5HTP measures, relative to vehicle control values (Table 4). Ingestion of the EAA2 formulation, however, produced a relatively modest reduction in the serum TYR ratio, and no reductions in cortical TYR concentrations or hypothalamic DOPA synthesis, compared to vehicle control values (Table 4). EAA2 intubation also did not modify the serum TRP ratio, cortex TRP levels or hypothalamic 5HTP synthesis, compared to control (although serum TRP concentrations were increased) (Table 4).

\section{Discussion}

The results of these studies show that (1) the oral administration of a mixture of BCAA to rats that reduces brain (hypothalamus) TRP concentrations and the rate of $5 \mathrm{HT}$ synthesis also diminishes TYR concentrations and catecholamine synthesis, (2) these

Amino Acids, Vol. 45, No. 5 (November 2013): pg. 1133-1142. DOI. This article is @ Springer and permission has been granted for this version to appear in e-Publications@Marquette. Springer does not grant permission for this article to be further copied/distributed or hosted elsewhere without the express permission from Springer. 
effects of BCAA ingestion on TYR concentrations and catecholamine synthesis can be prevented by the coadministration of TYR, without modifying the reduction in TRP concentrations and $5 \mathrm{HT}$ synthesis, (3) the ingestion of a mixture of EAA similar to that employed to enhance muscle protein synthesis (Tipton et al. 1999) does not produce reductions in brain TRP concentrations or its conversion to $5 \mathrm{HT}$, but does lower TYR concentrations and catecholamine synthesis, and (4) the administration of BCAA and EAA formulations to exercising rats produces similar effects to those seen in sedentary rats.

The biochemical relationship underlying these studies is that both TRP and TYR hydroxylases are not fully saturated at normal brain concentrations of TRP and TYR (e.g., see Fernstrom 1983). These enzymes catalyze the initial and rate-limiting steps in $5 \mathrm{HT}$ and catecholamine synthesis, respectively (Kaufman 1974). Consequently, the synthesis rate in the each pathway is stimulated in vivo by the administration of the appropriate precursor (TRP or TYR) (Moir and Eccleston 1968; Fernstrom and Wurtman 1971; Fernstrom 1983). Generally, however, increases in 5HT synthesis in response to TRP administration are more readily apparent than increases in DA or NE synthesis following TYR administration (Fernstrom 1983). Most likely, this reflects the fact that normal brain TRP concentrations [10-25 $\mu \mathrm{M}$ (Fernstrom and Fernstrom 1995c; Choi et al. 2009)] are below the apparent $K$ for TRP hydroxylase [25-50 $\mu \mathrm{M}$ (Friedman et al. 1972; Carlsson and Lindqvist 1978)], while TYR concentrations [100-150 $\mu \mathrm{M}$ (Choi et al. 2009)] are above its apparent $K$ for TYR hydroxylase [ 25 $\mu M$ (Carlsson and Lindqvist 1978)]. Hence, TYR hydroxylase is much closer to substrate saturation than is TRP hydroxylase and precursorinduced increases in overall synthesis in the catecholamine pathway would be expected to be smaller than those in the $5 \mathrm{HT}$ pathway. This may account for the variable effects of TYR administration previously observed on physical performance and mental function in soldiers and athletes (Struder et al. 1998; Lieberman 2003; Tumilty et al. 2011; Watson et al. 2012). However, since TYR hydroxylase is not fully saturated with substrate (Carlsson and Lindqvist 1978), the above considerations would also predict that reducing brain TYR concentrations might elicit a large reduction in catecholamine biosynthesis. Hence, consistent with the observations in the present studies, the administration of BCAA to athletes to reduce $5 \mathrm{HT}$

Amino Acids, Vol. 45, No. 5 (November 2013): pg. 1133-1142. DOI. This article is C Springer and permission has been granted for this version to appear in e-Publications@Marquette. Springer does not grant permission for this article to be further copied/distributed or hosted elsewhere without the express permission from Springer. 
synthesis and release would be expected also to reduce catecholamine synthesis and release (since enzyme saturation with substrate readily declines when substrate concentrations fall) (Carlsson and Lindqvist 1978; McTavish et al. 1999). In addition, adding sufficient TYR to the BCAA mixture to prevent the decline in brain TYR levels would be expected to block the reduction in catecholamine synthesis, since substrate saturation of TYR hydroxylase would not be diminished (as was observed).

The potential relevance of such biochemical findings to the effects of BCAA supplementation on physical performance (and central fatigue) seems straight-forward. Human and rat studies exploring for effects of drugs that increase $5 \mathrm{HT}$ synaptic transmission in brain have reported that elevating $5 \mathrm{HT}$ transmission reduces physical erformance (Wilson and Maughan 1992; Bailey et al. 1992, 1993; Struder et al. 1998). Conversely, drugs that increase catecholamine transmission enhance physical performance (Roelands et al. 2008a, b). Hence, the administration of BCAA to athletes, which the present findings show lowers both $5 \mathrm{HT}$ and catecholamine production in brain, should produce opposing effects on performance: the reduction in $5 \mathrm{HT}$ would increase, while the reduction in catecholamines would decrease physical performance and mental concentration. It would thus be interesting to examine the effects on physical performance in exercising human subjects of ingesting a supplement containing BCAA + TYR.

Athletes employ amino acid formulations for different purposes. For example, EAA mixtures are consumed in association with exercise (either as free amino acids or high-quality proteins) to maintain or possibly increase muscle protein synthesis and muscle mass (Tipton and Wolfe 2004; Tarnopolsky 2004; Phillips 2004). EAA mixtures contain BCAA, but also PHE and TRP. While athletes who use such amino acid mixtures are focused on muscle effects, we wondered what effects such EAA supplements would have on TRP and TYR (and their transmitter products) in brain. We chose an essential amino acid mixture employed in human studies of muscle protein synthesis (Tipton et al. 1999) and found that such a mixture (EAA1 in Table 3) did not have any effect on brain TRP concentrations and 5HT synthesis, compared to placebo, but produced a significant reduction

Amino Acids, Vol. 45, No. 5 (November 2013): pg. 1133-1142. DOI. This article is @ Springer and permission has been granted for this version to appear in e-Publications@Marquette. Springer does not grant permission for this article to be further copied/distributed or hosted elsewhere without the express permission from Springer. 
in TYR concentrations and catecholamine synthesis. Hence, if exercise increases 5HT function in brain, and this EAA mixture does not lower brain TRP and $5 \mathrm{HT}$, but does lower brain TYR and catecholamines, it might be predicted to exacerbate fatigue. We also evaluated another EAA mixture, formulated to contain the same BCAA content as that employed in the BCAA experiments, and other EAA with a concentration pattern derived from milk protein (see "Materials and methods"). Ingestion of this mixture did not lower brain TYR or catecholamine synthesis (but also did not lower brain TRP or 5HT). Hence, ingestion of this mixture by humans would be predicted to have no net impact on mental or physical performance in athletes (since the treatment did not modify any of the variables of interest). These considerations lead to the suggestion that with some experimentation, it may be possible to identify a pattern of EAA for a supplement that would maintain or perhaps enhance muscle protein synthesis (muscle mass), while at the same time lower brain TRP and $5 \mathrm{HT}$ without lowering TYR and catecholamines. Competitive transport of large LNAA into muscle appears not to be competitive physiologically (Pardridge 1979; Hundal et al. 1989), unlike that at the BBB, suggesting that amino acid mixtures may not be difficult to identify that achieve this objective.

\section{Acknowledgments}

These studies were supported by a grant from Ajinomoto North America.

\section{Conflict of interest}

John D. Fernstrom is an occasional scientific consultant to the Ajinomoto Company on matters unrelated to the content of this manuscript. The other authors declare that they have no conflict of interest.

\section{References}

Bailey SP, Davis JM, Ahlborn EN (1992) Effect of increased brain serotonergic activity on endurance performance in the rat. Acta Physiol Scand 145:75-76

Bailey SP, Davis JM, Ahlborn EN (1993) Serotonergic agonists and antagonists affect endurance performance in the rat. Int J Sports Med 14:330-333

Amino Acids, Vol. 45, No. 5 (November 2013): pg. 1133-1142. DOI. This article is (C Springer and permission has been granted for this version to appear in e-Publications@Marquette. Springer does not grant permission for this article to be further copied/distributed or hosted elsewhere without the express permission from Springer. 
NOT THE PUBLISHED VERSION; this is the author's final, peer-reviewed manuscript. The published version may be accessed by following the link in the citation at the bottom of the page.

Blomstrand E, Hassmen P, Ekblom B, Newsholme EA (1991) Administration of branchedchain amino acids during sustained exercise-effects on performance and on plasma concentration of some amino acids. Eur J Appl Physiol 63:83-88

Bongiovanni R, Yamamoto BK, Jaskiw GE (2001) Improved method for the measurement of large neutral amino acids in biological matrices. J Chromatog B 754:369-376

Carlsson A, Lindqvist M (1978) Dependence of 5-HT and catecholamine synthesis on concentrations of precursor amino acids in rat brain. Naunyn Schmied Arch Pharmacol 303:157-164

Choi S, DiSilvio B, Fernstrom MH, Fernstrom JD (2009) Meal ingestion, amino acids and brain neurotransmitters: effects of dietary protein source on serotonin and catecholamine synthesis rates. Physiol Behav 98:156162

Davis JM, Alderson NL, Welsh RS (2000) Serotonin and central nervous system fatigue: nutritional considerations. Am J Clin Nutr 72:573S$578 \mathrm{~S}$

Fernstrom JD (1983) Role of precursor availability in the control of monoamine biosynthesis in brain. Physiol Rev 63:484-546

Fernstrom JD, Faller DV (1978) Neutral amino acids in the brain: changes in response to food ingestion. J Neurochem 30:1531-1538

Fernstrom MH, Fernstrom JD (1987) Protein consumption increases tyrosine concentration and in vivo tyrosine hydroxylation rate in the lightadapted rat retina. Brain Res 401:392-396

Fernstrom MH, Fernstrom JD (1995a) Effect of chronic protein ingestion on rat central nervous system tyrosine levels and in vivo tyrosine hydroxylation rate. Brain Res 672:97-103

Fernstrom MH, Fernstrom JD (1995b) Acute tyrosine depletion reduces tyrosine hydroxylation rate in rat central nervous system. Life Sci 57:PL97-PL102

Fernstrom MH, Fernstrom JD (1995c) Brain tryptophan concentrations and serotonin synthesis remain responsive to food consumption after the ingestion of sequential meals. Am J Clin Nutr 61:312-319

Fernstrom JD, Wurtman RJ (1971) Brain serotonin content: physiological dependence on plasma tryptophan levels. Science 173:149-152

Fernstrom JD, Wurtman RJ (1972) Brain serotonin content: physiological regulation by plasma neutral amino acids. Science 178:414-416

Fernstrom MH, Volk EA, Fernstrom JD (1986) In vivo inhibition of tyrosine uptake into rat retina by large neutral but not acidic amino acids. Am J Physiol 251:E393-E399

Friedman PA, Kappelman AH, Kaufman S (1972) Partial purification and characterization of tryptophan hydroxylase from rabbit hindbrain. J Biol Chem 247:4165-4173

Amino Acids, Vol. 45, No. 5 (November 2013): pg. 1133-1142. DOI. This article is @ Springer and permission has been granted for this version to appear in e-Publications@Marquette. Springer does not grant permission for this article to be further copied/distributed or hosted elsewhere without the express permission from Springer. 
NOT THE PUBLISHED VERSION; this is the author's final, peer-reviewed manuscript. The published version may be accessed by following the link in the citation at the bottom of the page.

Gartside SE, Cowen PJ, Sharp T (1992) Evidence that the large neutral amino acid I-valine decreases electrically-evoked release of $5-\mathrm{HT}$ in rat hippocampus in vivo. Psychopharmacology 109:251-253

Gijsman HJ, Scarna A, Harmer CJ, McTavish SB, Odontiadis J, Cowen PJ, Goodwin GM (2002) A dose-finding study on the effects of branch chain amino acids on surrogate markers of brain dopamine function. Psychopharmacology 160:192-197

Hobson RM, Watson P, Maughan RJ (2013) Acute tryptophan depletion does not improve endurance cycling capacity in a warm environment. Amino Acids 44:983-991

Hundal HS, Rennie MJ, Watt PW (1989) Characteristics of acidic, basic and neutral amino acid transport in the perfused rat hindlimb. J Physiol Lond 408:93-114

Kaufman S (1974) Properties of the pterin-dependent aromatic amino acid hydroxylases. In: Wolstenholme GEW, FitzSimons DW (eds) Aromatic amino acids in the brain (CIBA foundation symposium 22 [New Series]). Elsevier, Amsterdam, pp 85-115

Lieberman HR (2003) Nutrition, brain function and cognitive performance. Appetite 40:245-254

McTavish SFB, Cowen PJ, Sharp T (1999) Effect of a tyrosine-free amino acid mixture on regional brain catecholamine synthesis and release.

Psychopharmacology 141:182-188

Meeusen R, Watson P, Hasegawa H, Roelands B, Piacentini MF (2006) Central fatigue: the serotonin hypothesis and beyond. Sports Med 36:881-909

Moir ATB, Eccleston D (1968) The effects of precursor loading in the cerebral metabolism of 5-hydroxyindoles. J Neurochem 15:1093-1108

Newsholme EA, Blomstrand E (1996) The plasma level of some amino acids and physical and mental fatigue. Experientia 52:413-415

Pardridge WM (1979) The role of blood-brain barrier transport of tryptophan and other neutral amino acids in the regulation of substrate-limited pathways of brain amino acid metabolism. J Neural Transm Suppl $15: 43-54$

Pardridge WM, Oldendorf WH (1975) Kinetic analysis of blood-brain barrier transport of amino acids. Biochim Biophys Acta 401:128-136

Paxinos G, Watson C (1982) The rat brain in stereotaxic coordinates. Academic Press, New York

Phillips SM (2004) Protein requirements and supplementation in strength sports. Nutrition 20:689-695

Roelands B, Hasegawa H, Watson P, Piacentini MF, Buyse L, De Schutter G, Meeusen R (2008a) The effects of acute dopamine reuptake inhibition on performance. Med Sci Sports Exerc 40:879-885

Roelands B, Goekint M, Heyman E, Piacentini MF, Watson P, Hasegawa H, Buyse L, Pauwels F, De Schutter G, Meeusen R (2008b) Acute

Amino Acids, Vol. 45, No. 5 (November 2013): pg. 1133-1142. DOI. This article is @ Springer and permission has been granted for this version to appear in e-Publications@Marquette. Springer does not grant permission for this article to be further copied/distributed or hosted elsewhere without the express permission from Springer. 
norepinephrine reuptake inhibition decreases performance in normal and high ambient temperature. J Appl Physiol 105:206- 212

Rouch C, Meile MJ, Orosco M (2003) Extracellular hypothalamic serotonin and plasma amino acids in response to sequential carbohydrate and protein meals. Nutr Neurosci 6:117-124

Smriga M, Kameishi M, Tanaka T, Kondoh T, Torii K (2002) Preference for a solution of branched-chain amino acids plus glutamine and arginine correlates with free running activity in rats: involvement of serotonergic-dependent processes of lateral hypothalamus. Nutr Neurosci 5:189-199

Struder HK, Hollmann W, Platen P, Donike M, Gotzmann A, Weber K (1998) Influence of paroxetine, branched-chain amino acids and tyrosine on neuroendocrine system responses and fatigue in humans. Horm Metab Res 30:188-194

Tarnopolsky M (2004) Protein requirements for endurance athletes. Nutrition 20:662-668

Tipton KD, Wolfe RR (2004) Protein and amino acids for athletes. J Sports Sci 22:65-79

Tipton KD, Ferrando AA, Phillips SM, Doyle D, Wolfe RR (1999) Postexercise net protein synthesis in human muscle from orally administered amino acids. Am J Physiol 276:E628-E634

Tumilty L, Davison G, Beckmann M, Thatcher R (2011) Oral tyrosine supplementation improves exercise capacity in the heat. Eur J Appl Physiol 111:2941-2950

US Department of Agriculture, Agricultural Research Service (2006) USDA national nutrient database for standard reference, Release 19. Nutrient database laboratory home page http://www.ars.usda.gov/nutrientdata Watson P, Hasegawa $H$, Roelands B, Piacentini MF, Looverie R, Meeusen R (2005) Acute dopamine/noradrenaline reuptake inhibition enhances human exercise performance in warm, but not temperate conditions. J Physiol 565:873-883

Watson P, Enever S, Page A, Stockwell J, Maughan RJ (2012) Tyrosine supplementation does not influence the capacity to perform prolonged exercise in a warm environment. Int J Sport Nutr Exerc Metab 22:363373

Wilson WM, Maughan RJ (1992) Evidence for a possible role of 5hydroxytryptamine in the genesis of fatigue in man: administration of paroxetine, a 5-HT re-uptake inhibitor, reduces the capacity to perform prolonged exercise. Exp Physiol 77:921-924

Wurtman RJ, Larin F, Mostafapour S, Fernstrom JD (1974) Brain catechol synthesis: control by brain tyrosine concentration. Science 185:183184

Amino Acids, Vol. 45, No. 5 (November 2013): pg. 1133-1142. DOI. This article is C Springer and permission has been granted for this version to appear in e-Publications@Marquette. Springer does not grant permission for this article to be further copied/distributed or hosted elsewhere without the express permission from Springer. 
NOT THE PUBLISHED VERSION; this is the author's final, peer-reviewed manuscript. The published version may be accessed by following the link in the citation at the bottom of the page.

Amino Acids, Vol. 45, No. 5 (November 2013): pg. 1133-1142. DOI. This article is @ Springer and permission has been granted for this version to appear in e-Publications@Marquette. Springer does not grant permission for this article to be further copied/distributed or hosted elsewhere without the express permission from Springer. 